\title{
EVALUATION OF MICROBIAL CONTROL OF THE COTTON LEAFWORM, Spodoptera littoralis (BOISD.) ON TOMATO PLANTS UNDER LABORATORY CONDITIONS Ragab, M.E. ${ }^{1}$; M-E-Elnaggar ${ }^{2}$ and Marwa G. Elmesawy ${ }^{2}$ \\ ${ }^{2}$ Plant Protection Research Inst., Agric. Research Center, Dokki, Giza
}

\begin{abstract}
Laboratory experiments were carried out to evaluate the effect of some microbial agents against the $2^{\text {nd }}$ and $4^{\text {th }}$ instar larvae of the cotton leafworm, Spodoptera littoralis (Boisd.) on tomato plants. Mortality percent of the $2^{\text {nd }}$ and $4^{\text {th }}$ instar larvae of $S$. littoralis increased with increasing duration after treatment with Bacillus thuringiensis kurstaki, S. littoralis NPV and Beauveria bassiana, as well as, increasing the concentration used. Positive correlation in mortality percentage of $S$. littoralis $2^{\text {nd }}$ and $4^{\text {th }}$ instar larvae with tested concentrations of $B$. thuringiensis kurstaki, whereas the higher concentration revealed higher mortality. Also, data indicated that the $2^{\text {nd }}$ instar larvae of $S$. littoralis was more susceptible to $B$. thuringiensis kurstaki, $S$. littoralis NPV and $B$. bassiana than the $4^{\text {th }}$ instar larvae.
\end{abstract}

\section{INTRODUCTION}

Vegetables are important components of the human diet since they provide essential nutrients required for most of the reactions occurring in the body. A high intake of vegetables (five or more servings per day) has been encouraged not only to prevent consequences due to vitamin deficiency but also to reduce the incidence of major diseases such as cancer, cardiovascular diseases and obesity. Like other crops, vegetables are attacked by insect pests during production and storage leading to damages that reduce the quality and the yield Hamam (2003). In order to reduce the loss and maintain the quality of vegetables, pesticides are used together with other pest management techniques during cropping to control pests. The use of pesticides have increased because they have rapid action, decrease toxins produced by food infecting organisms and are less labour intensive than other pest control methods. However, the use of insecticide, during production often leads to the presence of pesticide residues in vegetables after harvest Eman et al (1988). The presence of pesticide residues is a concern for consumers because pesticides are known to have potential harmful effects to other non-targeted organisms than pests. The major concerns are their toxic effects such as interfering with the reproductive systems and foetal development as well as their capacity to cause cancer and asthma (Gilden et al., 2010).

The cotton leafworm, Spodoptera littoralis (Boisd.) is one of the most serious and destructive pests, to cotton and many other field and vegetable crops. It is known that, $S$. littoralis the most important insect in agricultural systems in Egypt, especially vegetables. 
Ragab, M.E.et al.

The effect of natural compounds on $S$. littoralis have attracted the attention of many workers of the world including Egypt (Moawad, et al. 1996, Emam 1998, Reyad 2001 and Hamam 2003)

The present work aims to investigate the effect of some microbial agents against the cotton leafworm, S. littoralis on tomato plants.

\section{MATERIALS AND METHODS}

\section{Insect rearing:}

The cotton leafworm, Spodoptera littoralis (Boisd.) larvae were obtained from the laboratory culture of Plant Protection Research Institute Dokki, Giza. Newly hatched larvae from a single egg batch were introduced to pots containing the synthetic diet by using a soft hairbrush then transferred to plastic "poly pots" with dimensions of $5 \mathrm{~cm}$ deep and $10 \mathrm{~cm}$ internal diameter, containing the diet with $0.5 \mathrm{~cm}$ thick, which on cooling gave a very smooth surface. Ten larvae were reared in each plastic cup until reaching pupae. Freshly emerged moths were coupled in small glass jars provided with a filter paper as a site for egg-laying, and supplied with $10 \%$ sugar or honey solution in a piece of soaked cotton wool. All experiments were carried out under laboratory constant conditions of temperature $26 \pm 2^{\circ} \mathrm{C}$ and $60 \pm 5 \%$ $\mathrm{RH}$.

The following microbial agents were tested:

a. Biovar, an entomopathogenic fungi (3200 viable spore/mg), containing the fungus Beauveria bassiana. It was applied at a rate of $200 \mathrm{mg} / 100$ liter of water.

b. Protecto, W- $\mathrm{P}$ based on Bacillus thuringiensis subsp. Kurstaki (32x $10^{3} \mathrm{I}$. U/mg). Active ingredient $9.4 \%$ inert ingredient (Carrier) $90.6 \%$.

c. Viroset, active Ingredient: Spodoptera littoralis Nuclear Polyhedrosis Virus.

\section{Virulence of entomopathogens on S. littoralis:}

To study the virulence of entomopathogens on the cotton leafworm, $S$. littoralis, newly hatched larvae from a single egg batch was introduced to pots containing treated synthetic diet. Then the $2^{\text {nd }}$ and $4^{\text {th }}$ instar larvae were selected carefully to be used in this study. The tested larvae were almost similar in the weight and size.

\section{Leaf dipping technique:}

To evaluate the entomopathogen virulence against the $2^{\text {nd }}$ and $4^{\text {th }}$ instar larvae of $S$. littoralis, leaf dipping technique was used. Tested entomopathogen concentrations were prepared as follows:-

Beauveria bassiana was prepared at $32 \times 10^{3}, 16 \times 10^{3}, 8 \times 10^{3}, 4 \times$ $10^{3}$, and $2 \times 10^{3}$ conidia $/ \mathrm{ml}$. B. thuringeinsis kurstaki was prepared at concentrations of $64 \times 10^{3}, 32 \times 10^{3}, 16 \times 10^{3}, 8 \times 10^{3}$ and $4 \times 10^{3} \mathrm{CFU} / \mathrm{ml}$. while $S$. littoralis nuclear polyhedrosis virus was prepared at concentrations of $28 \times 10^{3}, 14 \times 10^{3}, 7 \times 10^{3}, 3.5 \times 10^{3}$ and $1.75 \times 10^{3} \mathrm{PIB} / \mathrm{ml}$. Second and fourth instar larvae were exposed for $48 \mathrm{~h}$ to treated tomato leaves, Lycopersicom esculentum by using dipping technique with conidial suspension. Four replicates were used for tested concentration of assayed 
entomopathogens. Each replicate in different treated concentrations and check contain twenty and ten larvae of both the $2^{\text {nd }}$ and $4^{\text {th }}$ instar, respectively. After preparation of tested concentrations of the three pathogens, tomato leaves were dipped in each concentration separately and left for air dryness. Then the treated leaves were offered to $S$. littoralis larvae for feeding for 48 hours. After feeding period, the mortality percentage was recorded and treated tomato leaves were replaced with another clean leaves for feeding whereas mortality counts were recorded every two days for ten days.

\section{Statistical analysis}

Cumulative mortality percentages were corrected using Abbott's formula (Abbott, 1925). The $\mathrm{IC}_{50}$ and $\mathrm{IC}_{90}$ values were calculated according to method of (Finney, 1971). Probit analysis was used to analyze data from bioassay experiments, such as the proportions of insects killed by several concentrations of an insecticide or at several time intervals at one or more concentrations of an insecticide. Results of Probit analysis are reported typically as a concentration or time required to kill a certain proportion of the test insects (for example, $\mathrm{LC}_{50}, \mathrm{LT}_{50}$ ); the slope and intercept of the regression line of the Probit-transformed data were also reported. useful form ):

In the equation of a straight line (when the equation is written in the

$$
\mathbf{Y}=\mathbf{a}+\mathbf{b X}
$$

The slope is the number "b" multiplied on $X$, "a" is the $Y$ intercept, where the line crosses the $Y$-axis

$Y=$ Mortality percentage

$\mathrm{X}=$ Concentration or time

\section{RESULTS AND DISCUSSION}

\section{Effect of Bacillus thuringiensis kurstaki on $2^{\text {nd }}$ and $4^{\text {th }}$ larval instars:}

Data in Table (1) showed that mortality percent of the $2^{\text {nd }}$ instar larvae of Spodoptera littoralis increased with increasing durations after treatment of $B$. thuringiensis kurstaki. After the $2^{\text {nd }}$ day of application, mortality percent was $40.25 \%$ at a concentration of $64 \times 10^{3} \mathrm{CFU} / \mathrm{ml}$, but it was $28.51,12.75$, 10.23 and $9.51 \%$ at concentrations $32,16,8$ and $4 \times 10^{3} \mathrm{CFU} / \mathrm{ml}$, respectively.

There was positive correlation in mortality percentage of $S$. littoralis $2^{\text {nd }}$ instar larvae with tested concentrations of $B$. thuringiensis kurstaki, whereas the higher concentration revealed higher mortality. For example, at $64 \times 10^{3}$ CFU $/ \mathrm{ml}$, mortality percentage ranged between 40.45 and $95.79 \%$, but it ranged $28.51-84.42 \%, 12.75-61.65 \%, 10.23-33.76 \%$ and $9.51-12.83 \%$ at concentrations of $32,16,8$ and $4 \times 103 \mathrm{CFU} / \mathrm{ml}$, respectively (Table, 1 ).

Data in Table (2) indicated that the $4^{\text {th }}$ instar larvae of $S$. littoralis was less susceptible to $B$. thuringiensis than the $2^{\text {nd }}$ instar larvae. Mortality percentage of the $4^{\text {th }}$ instar larvae increased with increasing the duration after treatment as well as increasing the concentration used of $B$. thuringiensis.

After the $4^{\text {th }}$ day of treatment, mortality percent was only $18.58 \%$ at the highest concentration, and $4.11 \%$ at the lowest one. Six days post 
treatment, mortality percentage at a concentration of $64 \times 10^{3} \mathrm{CFU} / \mathrm{ml}$ wad $22.95 \%$, but it was $19.35 \%, 12.04 \%, 9.75 \%$ and $7.25 \%$ at concentrations of $32,16,8$ and $4 \times 10^{3} \mathrm{CFU} / \mathrm{ml}$, respectively. Mortality percentage ranged between 8.66 and $39.67 \%$ after the $8^{\text {th }}$ day of treatment, while it ranged between $10.59 \%$ and $48.15 \%$ after 10 days (Table 2 ).

These results agree with those recorded by Naveen et. al. (2006) who found that the mortality of Heliothis armigera was higher in the $2^{\text {nd }}$ instar than in the $4^{\text {th }}$ instar larvae in all treatments. Similar results were obtained in case of Spodoptera exigua under both laboratory and greenhouse conditions.

Table (1): Corrected accumulative mortality percentage of S. littoralis $2^{\text {nd }}$ instar larvae fed on tomato leaves immersed in different concentrations of $B$. thuringiensis kurstaki .

\begin{tabular}{|c|c|c|c|c|c|}
\hline \multirow{2}{*}{$\begin{array}{c}\text { Conc. (CFU/ml) } \\
\times 10^{3} \mathrm{ml}\end{array}$} & \multicolumn{5}{|c|}{ Accumulative mortality\% indicated days after treatment } \\
\hline & 2 & 4 & 6 & 8 & 10 \\
\hline 4 & 9.51 & 8.25 & 12.68 & 9.38 & 12.83 \\
\hline 8 & 10.23 & 12.00 & 16.78 & 29.02 & 33.76 \\
\hline 16 & 12.75 & 20.23 & 29.85 & 58.40 & 61.65 \\
\hline 32 & 28.51 & 39.75 & 70.65 & 83.57 & 84.42 \\
\hline 64 & 40.45 & 65.54 & 82.72 & 65.92 & 9579 \\
\hline
\end{tabular}

Table (2): Corrected accumulative mortality percentage of S. littoralis $4^{\text {th }}$ instar larvae fed on tomato leaves immersed in different concentrations of $B$. thuringiensis kurstaki .

\begin{tabular}{|c|c|c|c|c|c|}
\hline $\begin{array}{c}\text { Conc. (CFU/mI) } \\
\mathbf{X ~ 1 0} \mathbf{~} \mathbf{~ m l}\end{array}$ & \multicolumn{5}{|c|}{ Accumulative mortality\% indicated days after treatment } \\
\cline { 2 - 6 } & $\mathbf{2}$ & $\mathbf{4}$ & $\mathbf{6}$ & $\mathbf{8}$ & $\mathbf{1 0}$ \\
\hline $\mathbf{4}$ & 0.00 & 4.11 & 7.25 & 8.66 & 10.59 \\
\hline $\mathbf{8}$ & 0.00 & 6.53 & 9.75 & 14.91 & 15.85 \\
\hline $\mathbf{1 6}$ & 0.00 & 10.85 & 12.04 & 15.62 & 19.22 \\
\hline $\mathbf{3 2}$ & 0.00 & 15.71 & 19.35 & 22.92 & 31.15 \\
\hline $\mathbf{6 4}$ & 0.00 & 18.58 & 22.95 & 39.67 & 48.15 \\
\hline
\end{tabular}

Effect of Spodoptera littoralis nuclear polyhedrosis virus (SINPV) on $2^{\text {nd }}$ and $4^{\text {th }}$ instar larvae:

Data in Table (3) showed that the mortality percent of the $2^{\text {nd }}$ instar larvae of $S$. littoralis increased with increasing duration after treatment of $S$. littoralis larvae with NPV. After the $2^{\text {nd }}$ day of application, S. littoralis NPV resulted in $20.54 \%, 18.50 \%, 8.75 \%, 6.23 \%$ and $3.51 \%$ mortality at concentrations of $28,14,7,3.5$ and $1.75 \times 10^{3} \mathrm{PIB} / \mathrm{ml}$, respectively. Mortality percentage was lower than $50 \%$ even at the highest concentration till the $6^{\text {th }}$ day after treatment. It ranged $8.45-32.34 \%$ and $9.60-42.62 \%$ after the $4^{\text {th }}$ and $6^{\text {th }}$ days of treatment, respectively.

There was positive correlation in mortality percentage of $S$. littoralis $2^{\text {nd }}$ instar larvae with tested concentrations of $S$. littoralis NPV, whereas the higher concentration revealed higher mortality.

Eight days post treatment the $2^{\text {nd }}$ instar larvae of $S$. littoralis fed on treated tomato leaves suffered, mortality of $57.21 \%$ at a concentration of 
$28 \times 10^{3} \mathrm{PIB} / \mathrm{ml}$, but it was $44.28 \%, 31.93 \%, 21.32 \%$ and $13.12 \%$ for the at concentrations of $14,7,3.5$ and $1.75 \times 10^{3} \mathrm{PIB} / \mathrm{ml}$, respectively. Mortality percentages were $81.30 \%, 66.72 \%, 49.02 \%, 31.52 \%$ and $17.41 \%$ for $S$. littoralis at the concentrations of $28,14,7,3.5$ and $1.75 \times 10^{3} \mathrm{PIB} / \mathrm{ml}$, respectively (Table 3 ).

Data in Table (4) indicated that mortality percentage of the $4^{\text {th }}$ instar larvae increased with increasing the duration after treatment, as well as, increasing the concentration used of $S$. littoralis NPV. Mortality percentages after the $4^{\text {th }}$ day of treatment were $7.40 \%, 6.11 \%, 4.28 \%, 2.15 \%$ and $0.0 \%$ at concentrations of $28,14,7,3.5$ and $1.75 \times 10^{3} \mathrm{PIB} / \mathrm{ml}$, respectively. After the $6^{\text {th }}$ day of treatment, mortality percentage ranged between $3.50 \%$ and $18.82 \%$, while it ranged $6.30-27.08 \%$ and $5.95-32.57 \%$ after the $8^{\text {th }}$ and $10^{\text {th }}$ days of feeding the $4^{\text {th }}$ instar larvae of $S$. littoralis on treated tomato leaves, respectively (Table 4).

Thus, it could be concluded that the $2^{\text {nd }}$ instar larvae of $S$. littoralis are more susceptible than the $4^{\text {th }}$ instar. Cumulative mortality percentage increased with increasing durations post treatment for both the $2^{\text {nd }}$ and $4^{\text {th }}$ instars. Higher concentration usage of $S$. littoralis NPV resulted in a higher larval mortality.

These results agree with those obtained by Mabrouk et al. (1996) who investigated the efficacy of different isolates of $S$. littoralis nuclear polyhedrosis virus (SLNPV). They recorded a positive correlation between the concentrations of the pathogen and the percentage of larval mortality. Second instars were more susceptible to NPV than $4^{\text {th }}$ instars, in general, mortality was low during the first three days following the NPV treatments, but increased gradually thereafter.

Table (3): Corrected accumulative mortality percentage of $S$. littoralis $2^{\text {nd }}$ instar larvae after feeding on tomato leaves immersed in a preparation of nuclear polyhedrosis virus.

\begin{tabular}{|c|c|c|c|c|c|}
\hline $\begin{array}{c}\text { Conc. } \\
\text { (PIB/mI) X 10 }\end{array}$ & \multicolumn{5}{c|}{ Accumulative mortality\% indicated days after treatment } \\
\hline $\mathbf{1 . 7 5}$ & $\mathbf{2}$ & $\mathbf{4}$ & $\mathbf{6}$ & $\mathbf{8}$ & $\mathbf{1 0}$ \\
\hline $\mathbf{3 . 5}$ & 6.51 & 8.45 & 9.60 & 13.12 & 17.41 \\
\hline $\mathbf{7}$ & 8.75 & 10.23 & 14.80 & 21.32 & 31.52 \\
\hline $\mathbf{1 4}$ & 18.50 & 23.55 & 17.05 & 31.93 & 49.02 \\
\hline $\mathbf{2 8}$ & 20.54 & 32.34 & 37.45 & 44.28 & 66.72 \\
\hline
\end{tabular}

Table (4): Corrected accumulative mortality percentage of S. littoralis $4^{\text {th }}$ instar larvae after feeding on tomato leaves immersed in a preparation of nuclear polyhedrosis virus.

\begin{tabular}{|c|c|c|c|c|c|}
\hline \multirow{2}{*}{$\begin{array}{c}\text { Conc. } \\
\text { (PIB } \mathbf{~ m l} \mathbf{X} \mathbf{~ 1 0} \mathbf{~} \mathbf{~ m l}\end{array}$} & \multicolumn{5}{|c|}{ Accumulative mortality\% indicated days after treatment } \\
\hline $\mathbf{1 . 7 5}$ & $\mathbf{2}$ & $\mathbf{4}$ & $\mathbf{6}$ & $\mathbf{8}$ & $\mathbf{1 0}$ \\
\hline $\mathbf{3 . 5}$ & 0.00 & 0.00 & 3.50 & 6.30 & 5.95 \\
\hline $\mathbf{7}$ & 0.00 & 2.15 & 6.12 & 9.79 & 9.99 \\
\hline $\mathbf{1 4}$ & 0.00 & 4.28 & 9.54 & 14.28 & 15.74 \\
\hline $\mathbf{2 8}$ & 0.00 & 7.40 & 13.35 & 20.07 & 23.32 \\
\hline
\end{tabular}


Effect of entomogenous fungus, Beauveria bassiana on $2^{\text {nd }}$ and $4^{\text {th }}$ instar larvae:

Data in Table (5) show that mortality percent of the $2^{\text {nd }}$ instar larvae of $S$. littoralis increased with increasing the duration after treatment of $B$. bassiana. Mortality percentage was $10.11 \%$ at a concentration of $32 \times 10^{3}$ $\mathrm{CFU} / \mathrm{ml}$ after the $2^{\text {nd }}$ day of application, but it was $22.24 \%, 30.25 \%, 44.09 \%$ and $64.47 \%$ after $4,6,8$ and 10 days of treatment at the same concentrations, respectively. Mortality percentage ranged between $9.12 \%$ and $53.31 \%$ at concentration of $16 \times 10^{3}$ conidia.ml, while it ranged from 6.60 $41.88 \%, 5.20-31.10 \%$, and $3.21-21.74 \%$ at concentrations of 8,4 and $2 \times 10^{3}$ conidia/ml, respectively.

There was positive trend in mortality percentage of $S$. littoralis $4^{\text {th }}$ instar larvae with tested concentrations of $B$. bassiana, as the higher concentrations resulted in higher mortalities. For example, at $32 \times 10^{3}$ condia/ml, mortality percentage ranged between $8.50 \%$ and $38.12 \%$, but it ranged from $6.15-$ $30.18 \%, 5.50-22.15 \%, 4.25-14.00 \%$ and $0.00 \%-10.65 \%$ at concentrations of $16,8,4$ and $2 \times 10^{3}$ conidia/ml, respectively (Table 6). After the $4^{\text {th }}$ and 6 days of treatment, mortality percent was lower than $20 \%$ even at highest concentration. It ranged between $0.00 \%$ and $8.50 \%$ in the $4^{\text {th }}$ day post treatment, and from 3.65 to $18.62 \%$ in the $6^{\text {th }}$ day after feeding of $S$. littoralis larvae on treated tomato, respectively. Generally, the $4^{\text {th }}$ instar larvae of $S$. littoralis reflected lower susceptibility (or more tolerance) towards $B$. bassiana as compared to the $2^{\text {nd }}$ instar larvae.

Table (5): Corrected accumulative mortality percentage of S. littoralis $2^{\text {nd }}$ instar larvae fed on tomato leaves immersed in different concentrations of $B$. bassiana.

\begin{tabular}{|c|c|c|c|c|c|}
\hline \multirow{2}{*}{$\begin{array}{c}\text { Conc. } \\
\text { (conidia/ml) } \\
\times 10^{3} \mathrm{ml}\end{array}$} & \multicolumn{5}{|c|}{ Accumulative mortality\% indicated days after treatment } \\
\hline & 2 & 4 & 6 & 8 & 10 \\
\hline 2 & 3.21 & 6.20 & 10.11 & 19.04 & 21.74 \\
\hline 4 & 5.20 & 8.00 & 14.28 & 24.37 & 31.10 \\
\hline 8 & 6.60 & 12.25 & 19.60 & 30.41 & 41.88 \\
\hline 16 & 9.12 & 19.50 & 25.44 & 37.08 & 53.31 \\
\hline 32 & 10.11 & 22.24 & 30.25 & 44.09 & 64.47 \\
\hline
\end{tabular}

Table (6): Corrected Accumulative mortality percentage of S. littoralis $4^{\text {th }}$ instar larvae fed on tomato leaves immersed in different concentration of $B$. bassiana .

\begin{tabular}{|c|c|c|c|c|c|}
\hline $\begin{array}{c}\text { Conc. } \\
\left(\begin{array}{c}\text { condia/ } \mathbf{~ m l}) \\
\mathbf{X} \mathbf{1 0}^{\mathbf{3}} \mathbf{~ m l}\end{array}\right.\end{array}$ & $\mathbf{2}$ & $\mathbf{4}$ & $\mathbf{6}$ & $\mathbf{8}$ & $\mathbf{1 0}$ \\
\hline $\mathbf{2}$ & 0.00 & 0.00 & 3.65 & 5.25 & 10.65 \\
\hline $\mathbf{4}$ & 0.00 & 4.25 & 7.50 & 10.50 & 14.00 \\
\hline $\mathbf{8}$ & 0.00 & 5.50 & 9.10 & 12.80 & 22.45 \\
\hline $\mathbf{1 6}$ & 0.00 & 6.15 & 12.16 & 18.50 & 30.18 \\
\hline $\mathbf{3 2}$ & 0.00 & 8.50 & 18.62 & 25.60 & 38.12 \\
\hline
\end{tabular}


Reviewing above mentioned results, it could be concluded that the $2^{\text {nd }}$ instar larvae of $S$. littoralis are more susceptible to $B$. bassiana than the $4^{\text {th }}$ instar larvae. This difference of virulence against larval instars depends on instar response difference due to it's integument composition and fungus ability to penetrate the cuticle layer. Furthermore, it is known that early instars are the most susceptible, with percent mortality ranging up to 100 depending on the dosage and the isolate (Feng, et. al. 1985).

Potency of entomopathogens against the $2^{\text {nd }}$ and $4^{\text {th }}$ instar larvae of $S$. littoralis

Data in Table (7) showed Potency of entomopathogens against the $2^{\text {nd }}$ and $4^{\text {th }}$ instar larvae of $S$. Ittoralis after 10 days post treatment with treated tomato leaves using leaf dipping technique expressed as $\mathrm{LC}_{50}$, and $\mathrm{LC}_{90}$. It clear from data the $2^{\text {nd }}$ instar larvae was more susceptible to different entomopathogens than the $4^{\text {th }}$ instar larvae of $S$. Ittoralis.

For the $2^{\text {nd }}$ instar larvae $S$. Ittoralis NPV was the most effective followed discendingly by $B$. thuringiensis and $B$. bassiana, respectively. The $\mathrm{LC}_{50}$ value was $7.26 \times 10^{3} \mathrm{PIB} / \mathrm{ml}$ for $S$. littoralis NPV, while it was $12.01 \times 10^{3}$ $\mathrm{CFU} / \mathrm{ml}$ and $26.20 \times 10^{3}$ conidia/ml for $B$. thuringiensis and $B$. bassiana, respectively

Regarding the $4^{\text {th }}$ instar larvae $B$. thuringiensis was the most effective followed discendingly by $S$. Ittoralis NPV and $B$. bassiana, respectively. The $L C_{50}$ value was $83.47 \times 10^{3}$ conidia $/ \mathrm{ml}$ for $B$. thuringiensis, while it was $86.79 \times 10^{3} \mathrm{PIB} / \mathrm{ml}$ and $125.41 \times 10^{3}$ conidia $/ \mathrm{ml}$ for S. Ittoralis NPV and $B$. bassiana, respectively

Reviewing the above mentioned results, it appear that the potency of pathogen differ according to the larval instar of $S$. littoralis. While the $2^{\text {nd }}$ instar larvae were more susceptible to the three tested pathogens than the $4^{\text {th }}$ instar larvae. Furthermore, efficacy the same pathogen on larval instars of insect differ from instar to the other. This difference depending on different factors. For example, in the case of $B$. thuringiensis because of their peptidic nature and insecticidal activities, effect of midgut $\mathrm{pH}$ on insecticidal protein soulubility, binding success of Cry1 $\mathrm{Ab}$ toxin to larval brush border membrane vesicles (BBMV) (Hofmann, et. al. 1988 Aronson, et. al. 1991; Tabashnik, et. al. 1994; Grochulski, et. al. 1995; Tang, et. al. 1996; Soberon, et. al. 2000; Oppert, et. al. 1997).

Tacking into account the potency of S. littoralis NPV, it is clear that the pathogenicity decreased with increasing larval instars. This agree with ElSaadany et al. (1992b). They indicated that high larval density method was superior to the Oxford method as a means of infecting larvae of $S$. littoralis. The percentage mortality of heavy larvae was less than that of lighter larvae and the net yield of PIBs was considerably higher in older larvae. Treating larvae individually resulted in higher net yields of PIB compared with the Oxford method.

As for $B$. bassiana, The difference of virulence against larval instars depends on instar response difference due to it's integument composition and fungus ability to penetrate the cuticle layer. Furthermore, it is known that first instars are the most susceptible, with percent mortality ranging up to $100 \%$ depending on the dosage and the isolate (Feng, et. al. 1985). 
Ragab, M.E.et al.

Table (7): LC 50 , LC 90 , Confidence Limite and Slope Values of $B$. thuringiensis kurstaki, S. littoralis NPV and B. bassiana after feeding the $2^{\text {nd }}$ and $4^{\text {th }}$ instar larvae of $\mathbf{S}$. littoralis on treated castor bean leaves for 48 hours at indicated days after treatment

\begin{tabular}{|c|c|c|c|c|c|c|}
\hline \multirow{2}{*}{$\begin{array}{l}\text { Days after } \\
\text { treatments }\end{array}$} & \multirow{2}{*}{$\begin{array}{l}\mathrm{LC}_{50} \\
\times 10^{3}\end{array}$} & \multirow{2}{*}{$\begin{array}{l}L^{L} C_{90} \\
\times 10^{3}\end{array}$} & \multicolumn{2}{|c|}{ Confidence Limit } & \multirow{2}{*}{$\begin{array}{c}\text { Slope } \pm \\
\text { SE }\end{array}$} & \multirow{2}{*}{$\begin{array}{l}\text { Intercept } \\
\text { (a) + SE }\end{array}$} \\
\hline & & & Lower $\times 10^{3}$ & Upper $\times 10^{3}$ & & \\
\hline \multicolumn{7}{|c|}{$2^{\text {nd }}$ instar larvae } \\
\hline B. thuringiensis & 12.01 & 41.56 & 3.19 & 30.18 & $2.54 \pm 0.54$ & $2.43 \pm 0.70$ \\
\hline B. bassiana & 26.20 & 572.65 & 16.99 & 50.60 & $3.64+0.29$ & $3.64+0.28$ \\
\hline S. littoralis NPV & 7.26 & 50.80 & 5.41 & 9.81 & $3.69 \pm 0.22$ & $1.52 \pm 0.24$ \\
\hline \multicolumn{7}{|c|}{$4^{\text {th }}$ instar larvae } \\
\hline B. thuringiensis & 83.47 & 1466.99 & 46.31 & 335.88 & $1.02 \pm 0.25$ & $3.02 \pm 0.34$ \\
\hline B. bassiana & 125.41 & 2973.44 & 59.16 & 1083.48 & $0.93 \pm 0.25$ & $3.04+0.34$ \\
\hline S. littoralis NPV & 86.79 & 2150.34 & 34.64 & 1838.3 & $0.92+0.27$ & $3.21+0.28$ \\
\hline
\end{tabular}

\section{REFERENCES}

Abbott, W.S. (1925). A method of computing the effectiveness of insecticides. J. Econ. Entomol., 18: 265-267.

Aronson, A. I., E.-S. Han, W. McGaughey, and D. Johnson (1991): The solubility of inclusion proteins from Bacillus thuringiensis is dependent upon protoxin composition and is a factor in toxicity to insects. Appl. Environ. Microbiol. 57:981-986.

Emam, A. K.; S. A. El-Refai and D. Degheele (1998): Effect of sublethal dosages of four chitin synthesis inhibitors on the reproduction potential and F1 generation of the Egyptian cotton leafworm, Spodoptera littoralis. Med. Fac. Landbow. Rijksuniv, Gent. 53 (1): 249-54.

Feng, Z., Carruthers, R. I., Roberts, D. W. and Robson, D. S. 1985. Age specific dose mortality effects of Beauveria bassiana (Deuteromycotina: Hyphomycetes) on the European corn borer Ostrinia nubilalis (Lepidoptera: Pyralidae). J. Znvertebr. Pathol. 46,259-264.

Finney, D. J. (1971): Probit analysis. Cambridge Univ. Press Cambridge, 33.

Gilden, R. C., Huffling, K. and Sattler, B. (2010): Pesticides and Health Risks. JOGNN, 39:103-110.

Grochulski, P., L. Masson, S. Borisova, M. Pusztai-Carey, J.-L. Schwartz, R. Brousseau, and M. Cygler. 1995. Bacillus thuringiensis CrylA(a) insecticidal toxin: crystal structure and channel formation. J. Mol. Biol. 254:447-464.

Hamam, M. (2003): Development and proving of biocontrol methods based on Bacillus thuringiensis and entomopathogenic fungi against the cotton pests Spodoptera littoralis, Helicoverpa armigera (Lepidoptera: Noctuidae) and Aphid gossypii (Homoptera: Aphididae). Ph.D. Thesis, Institute of Plant Pathology and Applied Zoology, Justus-Liebig-Univ., Giessen, Germany, 130p.

Hofmann, C., H. Vanderbruggen, H. Höfte, J. Van Rie, S. Jansens, and H. Van Mellaert (1988b): Specificity of Bacillus thuringiensis $\delta$-endotoxins is correlated with the presence of high-affinity binding sites in the brush border membrane of target insect midguts. Proc. Natl. Acad. Sci. USA 85:7844-7848. 
Mabrouk, A.M.; H.K.M. Bekheit and G.M. Moawad (1996). Improvement of Spodoptera littoralis mass rearing technique for production of NPV. Egypt. J. Biol. Pest Control, 6 (2): 200-205.

Moawad, G. M.; E. M. Salem; W. M. Desuky; A. A. El-Sheakh and S. A. Raslan (1996): Latent effect of IGR's on egg-masses of Spodoptera littoralis (Boisd.) treated with three IGR's. J. Agric. Res., 74 (1): 115-22.

Naveen A.; Markus, H. and Thies B. (2006): Evaluation of bio-rational insecticides to control Helicoverpa armigera (Hübner) and Spodoptera exigua (Hübner) (Lepidoptera: Noctuidae) fed on Vicia faba I. mitt. dtsch. ges. allg. angew. ent. 15:245-250.

Oppert, B., K. J. Kramer, R. W. Beeman, D. Johnson, and W. H. Mcgaughey (1997): Proteinase-mediated insect resistance to Bacillus thuringiensistoxins. J. Biol. Chem. 272:23473-23476.

Reyad, N. f. (2001): Abundance and control studies on Spodoptera littoralis (Boisd.) infesting certain vegetables. M. Sc. Thesis, Fac. Sci., Unvi. Cairo. 85pp.

Soberon, M., R. V. Perez, M. E. Nunez-Valdez, A. Lorence, I. Gomez, J. Sanchez, and A. Bravo. 2000. Evidence for intermolecular interaction as a necessary step for pore-formation activity and toxicity of Bacillus thuringiensis Cry1Ab toxin. FEMS Microbiol. Lett. 191:221-225.

Tabashnik, B. E., N. Finson, F. R. Groeters, W. J. Moar, M. W. Johnson, K. Luo, and M. J. Adang. 1994. Reversal of resistance to Bacillus thuringiensis in Plutella xylostella. Proc. Natl. Acad. Sci. USA 91:41204124.

Tang, J. D., A. M. Shelton, J. Van Rie, S. De Roeck, W. J. Moar, R. T. Roush, and M. Peferoen. 1996. Toxicity of Bacillus thuringiensis spore and crystal protein to resistant diamondback moth (Plutella xylostella). Appl. Environ. Microbiol. 62:564-569.

$$
\begin{aligned}
& \text { تقييم المكافحة الميكروبية لاودة ورق القطن على نباتات الطماطم تحت الظروف المعملية }
\end{aligned}
$$

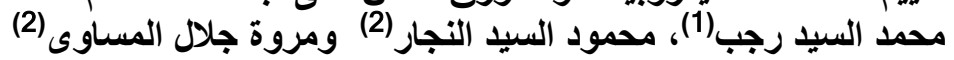

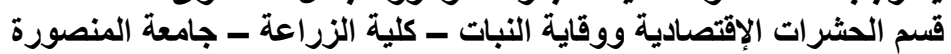

$$
\begin{aligned}
& \text { معهد بحوث وقاية النباتات ـ مركز البحوث الزراتية ـاعية ـ الاقي - جيزة }
\end{aligned}
$$

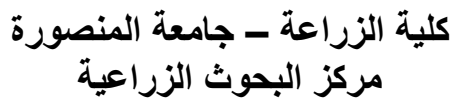


Ragab, M.E.et al. 